\title{
The Impact of Malakah Based on Halaqah at Pondok Learning Institutions
}

Mohd Zahirwan Halim Zainal Abidin, Nooraileen Ibrahim, Abd. Munir Mohd Noh, Hamdi Rahman Mohd Yaacob, Ahmad Rozaini Ali Hassan, Juriah Mohd Amin

To Link this Article: http://dx.doi.org/10.6007/IJARBSS/v11-i5/10017 DOI:10.6007/IJARBSS/v11-i5/10017

Received: 01 April 2021, Revised: 28 April 2021, Accepted: 13 May 2021

Published Online: 24 May 2021

In-Text Citation: (Abidin et al., 2021)

To Cite this Article: Abidin, M. Z. H. Z., Ibrahim, N., Noh, A. M. M., Yaacob, H. R. M., Hassan, A. R. A., \& Amin, J. M. (2021). The Impact of Malakah Based on Halaqah at Pondok Learning Institutions. International Journal of Academic Research in Business and Social Sciences, 11(5), 654-668.

Copyright: (c) 2021 The Author(s)

Published by Human Resource Management Academic Research Society (www.hrmars.com) This article is published under the Creative Commons Attribution (CC BY 4.0) license. Anyone may reproduce, distribute, translate and create derivative works of this article (for both commercial and non-commercial purposes), subject to full attribution to the original publication and authors. The full terms of this license may be seen at: http://creativecommons.org/licences/by/4.0/legalcode

Vol. 11, No. 5, 2021, Pg. 654 - 668

Full Terms \& Conditions of access and use can be found at http://hrmars.com/index.php/pages/detail/publication-ethics 


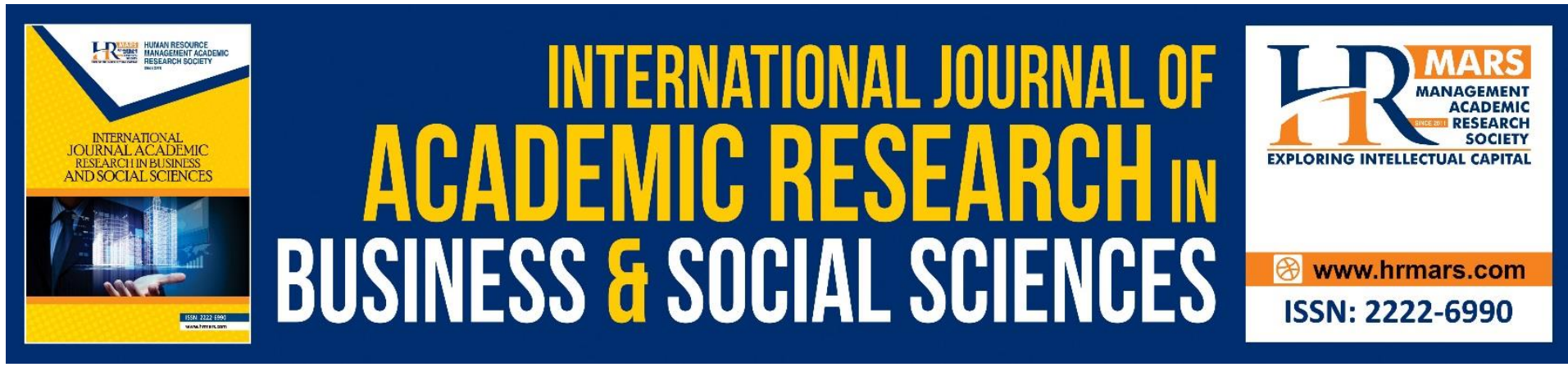

\title{
The Impact of Malakah Based on Halaqah at Pondok Learning Institutions
}

\author{
Mohd Zahirwan Halim Zainal Abidin', Nooraileen Ibrahim², Abd. \\ Munir Mohd Noh'1, Hamdi Rahman Mohd Yaacob1, Ahmad \\ Rozaini Ali Hassan ${ }^{1}$, Juriah Mohd Amin ${ }^{1}$ \\ ${ }^{1}$ Academy of Islamic Contemporary Studies Universiti Teknologi MARA Perak Branch, Seri \\ Iskandar, 32610, Bandar Baru Seri Iskandar, Perak, Malaysia, ${ }^{2}$ Academy of Language Studies \\ Universiti Teknologi MARA Perak Branch, Seri Iskandar, 32610, Bandar Baru Seri Iskandar, \\ Perak, Malaysia \\ Email: mohdz560@.uitm.edu.my
}

\begin{abstract}
Ibnu Khaldun (1332-1406 AD) had proposed the concept of malakah based on the view that knowledge can be completely internalised and be applied in daily life. Knowledge that has been truly internalised will determine the attitude, habit and behaviour of an individual either in a positive or negative manner. The learning process that an individual undergoes formally or informally will result in malakah that has been internalised by the said individual. In the context of Islamic education in Malaysia particularly, the pondok learning institution is one of the institutions that has produced many renowned religious scholars since it first established. Obviously, the contribution of this institution has an immense impact and cannot be denied. As one of the earliest centres of formal Islamic education in Malaysia, the religious scholars have focused solely on the halaqah method in their efforts to produce countless learned individuals who are not only knowledgeable and excelled in religious matters but also in the aspect of academic matters too. Therefore, this study is focussing on the malakah implication based on halaqah at pondok learning institutions. To achieve this objective, this study is a qualitative research based on library research and in-depth interviews. The contents of the acquired data will be analysed descriptively. The findings of this study found that most of the religious instructors or students have applied the knowledge acquired and have also conveyed it to the community at large. The charismatic manner and the manner in which the acquired knowledge has been put to practice have reflected that knowledge has truly been internalised and has a deep impact on the character and personality of the individuals. Therefore, this is in line with the Islamic teachings.
\end{abstract}

Keywords: Malakah, Pondok, Halaqah, Knowledge, Character, Practice

\section{Introduction}

The implementation of the appropriate teaching methods will result in critical and creative thinking skills that are in accordance with Islamic teachings without neglecting the spiritual aspect. Moreover, the end result is an individual that has fulfilled his potential and 
capacity as an excellent human being and can equally balance worldly demands without sacrificing his religious and moral obligations. The relationship between the teaching and learning process has an overwhelmingly large influence not only on the way the knowledge is acquired but also in the manner it is mastered, applied and lead to the development of the attitude and spiritual aspect of an individual. A comprehensive education is a significant aspect and the essence in the establishment of Islamic civilisation in the history of mankind. Islam recognises and puts an emphasis on the value of knowledge acquired through the education process as this knowledge is the one aspect that differentiates man from others (Hambali \& Kadir, 2005). According to Ibnu Khaldun (1332-1406 AD), learning is a life-long process in which it has the power to completely transform an individual from one who is ignorant to one who is knowledgeable and truly enlightened. This has been proven through observation and clear signs that knowledge has the power to change someone to become better than he was before. Thus, mankind is able to internalise and apply knowledge as well as the values gained from it to bring a sense of completion to their lives (Long, 2015).

\section{Research Methodology}

This study is focuses on content and descriptive analysis based on qualitative method referring to documents analysis and interviews. The document analysis includes a books, journals and proceedings. The data will be analyzed to obtain real information about the study. According to Lebar (2017), analysis of documents and records is essential to understand the history and environment related to the study conducted. The documents or records obtained have a variety of important information regarding the life, population, beliefs, culture and values of the community in the place studied.

The interview will be conducted by the researcher to obtain information on facts, trust, feelings and needs to achieve an objective. The interview process will use semi-structured interviews. These interviews use questions that have been framed before the interview session is conducted, however the interviewer can ask to confirm the respondent's answers to a formal question asked and adapt the questions according to the situation also gain the desired response from the respondents (Piau, 2011).

\section{The Malakah Concept Based On The Perspective Of Ibnu Khaldun (1332-1406 AD)}

Ibnu Khaldun (1332-1406 AD) is a renowned and respected historian as well as Islamic scholar in various fields such as politics, social, economic and education. The ideals propounded by him as been the basis of numerous studies of intellectuals until the present day (Majid \& Hamat, 2005). Ibnu Khaldun has indeed made an immense contribution to the body of knowledge in terms of the teaching methods and techniques in Islamic education through his written works and have greatly influenced scholars until today ( Na'miy, 1994). According to Ibnu Khaldun there are various methods that can be applied in the teaching and learning process particularly the talqin method (watch and listen), al-Tajribah (attempt to replicate) and al-Tikrar (repeat) (Noh, 2015). Besides that, the al-tadarruj method (in stages) was emphasised by Ibnu Khaldun in ensuring mastery of the acquired knowledge in various stages: moderate, difficult and extremely difficult. With the implementation of these methods, the students will achieve the desired malakah as a result of the learning process and various exercises conducted repeatedly. As a result, these students will gain the knowledge and put into practice the values that have been acquired in the process. In the end, this will lead to a holistic individual. malakah that is based on experience, understanding, 
problem-solving and sustainability will enable the students to manage their lives well and productively. Furthermore, they will also be able to resolve problems well with a fresh perspective which will result in an amicable solution or agreement (Hamzah, 2010).

The word malakah used by Ibnu Khaldun in his text al-Muqaddimah has various meanings depending on the respective topic of discussion. In this particular text, the word malakah can be defined as knowledge, skill, talent, leadership, assumption and norms (Zainol et.al., 2018). Malakah from a linguistic standpoint means something to be acquired or mastered and a characteristic that is internalised. Ibnu Khaldun concluded that malakah is an internalised or ingrained characteristic of an individual. malakah is the mastery of a body of knowledge and skills which will lead to character-building as a result of the learning process and the commitment shown in acquiring the said knowledge and skills. Furthermore, malakah also has an impact on the optimum mastery of knowledge that encompassed cognitive, effective and psychomotor skills (Anwar, 2008). Moreover, malakah also includes mastery and expertise in acquiring knowledge holistically which can be applied in daily life. In addition, a coherent malakah process will lead to knowledge that is able to transform the thinking process of an individual in a positive light. Therefore, malakah can be defined as mastery and expertise of knowledge based on revelation (naqli) and intellect (aqli) in a unique and in-depth manner (Zainol et.al., 2018).

Malakah can also be internalised through the "deep" and "achieving" process by students. This is based on the condition that they master the acquired knowledge through the process of comprehension and memorisation. During this process, the students must optimise their learning process and also do numerous exercises to further strengthen malakah. The religious instructor or teacher not only imparts knowledge but also conducts numerous discussion sessions as a method of improving malakah (Zeki \& Moshidi, 2017).

\section{Education Based on Halaqah at Pondok Learning Institutions}

The history of the establishment and spread of Islamic education in Tanah Melayu was based on the pondok system which was actually unplanned or a mere coincidence. Islamic education was established by individuals that returned from Mekah after they had gained religious knowledge after a long period of time. Upon their return, there was a growing interest in religious knowledge which led to droves of people eager to learn more deeply about Islam from these religious scholars. As a result, the first pondok learning institution was establised with these religious scholars as the founding fathers (Badaruddin, 2007). The pondok learning institution was established by scholars that returned from religious studies in the Middle East with the aim of imparting religious knowledge to the community at large. The establishment of the pondok learning institution is also due to the high number of students that came from other areas. The number of people that came to acquire knowledge kept on rising that accomodation had to be provided to these students.

The pondok learning institution was based on the religious learning institutions in Mekah and Cairo (Rahim \& Bakar, 2015). The development of the pondok learning institution is also influenced by the pondok learning institution system in Acheh, Sumatera and Patani (Manaf, 2001 ; Saadon, et.al., 2016). In the beginning, the pondok learning institution was considered the best and was the top choice of the Muslim community in gaining knowledge related to Islam. The institution continued with the traditional learning method that had dominated most of Islamic education at that time (Ismail et.al., 2014). The pondok learning institution was also one of the earliest centres of formal education at that period of time in 
the Malay Archipelago. This institution was established to fulfill the demands and needs of the Muslim community that needed the knowledge and guidance in matters related to akidah and worship (Rawi et.al.,2015). The sanctity of Islam was preserved and not influenced by Christianity and Western ideals because of the strong influence of the pondok learning institution. This institution was also able to enlighten many individuals about Islam which ultimately led to them become renowned Islamic scholars (Ismail, 2014).

The halaqah method is a circle or semi-circle learning method that was used predominantly in most centres of Islamic institutions which also includes the pondok learning institutions. Halaqah can be defined as the learning process that includes groups of people with not more than 12 students per group (Qadiri, 1993). However, some views say that the number of students could be around 5 or even up to 500 (Dhofier, 2011). Halaqah is when students will sit cross-legged on the floor in a circle or semi-cirle to listen to the explanation of their teacher sitted in the middle. The teacher will explain a chosen text written by the teacher himself or another religious scholar. The students will be referring to the text chosen by their respective teachers in the halaqah (Hamid, 2010; Muslimin, 2015; Dhofier, 2011). In Islamic education, halaqah is done in many ways - in a circle where the students are sitted on the floor facing the teacher who is sitted on a chair or in a classroom where everyone is sitted at their own desks and chairs. (Abdullah, Interview, 2018). Besides that, a halaqah is also when the teacher is sitted right in the middle and surrounded by his students. This method or halaqah system was first introduced at Masjidil Haram and Masjid Nabawi and was soon gradually adopted by the pondok learning institution in the Malay Archipelago.

Pondok learning institution is the earliest formal learning institution established in the Archipelago. The halaqah method has remained and is still conducted in the pondok institutions in the Archipealgo because most of the religious teachers were educated at Masjidil Haram, Mekah. Islamic education has applied the halaqah method in its education system at Masjidil Haram. The religious teachers of the pondok that were educated at Masjidil Haram has implemented the halaqah method in their teaching process upon returning to the Archipelago. The halaqah method has become synonymous with the pondok education system since its establishment including the ones in Kelantan. This halaqah method has been passed down by Rasulullah (SAW) and still remains relevant to this day and age particularly at the pondok learning institution. Furthermore, this method has its own uniqueness and provides benefits although it is a traditional method in the Islamic education system.

At present, the total number of pondok learning institutions in Malaysia that remain active and implements the halaqah method are approximately 100. In Kelantan, there are 39 whereas in Terengganu about 12. Besides that, in the northern region of Malaysia namely Perlis, Kedah and Penang there are approximately a total of 30 (Rawi et.al., 2015). There are several aspects that have elevated the status of the pondok learning institutions as one of the best in the Archipelago. Some of these aspects include the knowledgeable and wise religious scholars that are highly reputable and the teaching and learning methods implemented which have received a favourable response from the students. Thus, all these factors combined have made the pondok learning institution as the top choice and has gained the same kind of prestige as other learning institutions such as schools, madrasahs and also universities.

\section{The Impact of Malakah Based on Halaqah at Pondok Learning Institutions}

The pondok learning institution has implemented methods such as the halaqah method which emphasized on aspects in Islamic education which include insan, knowledge, meaning and purpose. Furthermore, the institution emphasized on aspects comprising 
spirituality, internalization, good attitude, knowledge, practice and excellent character. This is in line with the aspirations of the government in producing holistic individuals that truly comprehend and practice Islam as a way of life (Suhid \& Fakhruddin, 2012). In other words, halaqah encompasses positive values based on Islamic religious knowledge resulting in individuals that practice what they preach. There are many positive aspects of the halaqah method. Thus, the impact of malakah through the halaqah method at pondok learning institutions include the following:

\section{Reinforcement of Akidah and Syariat}

The halaqah method is one of the methods in the universal Islamic education system. This method has been proven to produce individuals that abide by the laws of Allah SWT and have a deep understanding of Islam as a direct result of the knowledge they acquired ( Rosmanah, 2013). Halaqah is integral in the process of strengthening faith and religious beliefs while at the same time producing individuals that abide by religious laws and prohibitions. In addition, halaqah will improve acts of worship to Allah SWT. This is because worship to Allah SWT is one of the main purposes of the creation of man (Qadiri, 1993). This entire process will assist the student on a self-discovery journey, develop a strong character as well as develop a sense of teamwork (Umami, 2015).

In the aspect of worship, halaqah will encourage Muslims to perform their acts of worship in a dutiful and steadfast manner. Worshipping Allah SWT requires all Muslims to be sincere and be full of humility be it while performing specific or general acts of worship. Thus, the halaqah method is a medium of propagating Islam to the masses particularly in explaining certain aspects of Islam with the aim to enlighten others. Moreover, this method will lead to character-building of an individual who will abide with religious matters namely related to akidah, syariat and good character. Students that have equipped themselves with religious knowledge with the utmost sincerity and consistency will put the values they learnt into practice. The emphasis on sincerity in the pursuit of knowledge is reflected in the transcription of an interview as seen below:

"Yes, I am interested in the halaqah learning method. In addition, my main purpose is to gain a deeper understanding of religious knowledge....if we are hardworking, we will gain more knowledge...but if we are lazy, we will not gain much knowledge..."

$$
\text { (inf1/S1/Int/Hm.PLT/22/3/2017) }
$$

"Yes. We need to have the right intention in pursuing knowledge which is to gain the blessing of Allah SWT in order to gain more blessings and mastery of the acquired knowledge. One day, the knowledge I have gained will be shared with other people when I am teaching at the masjid and other places"

$$
\text { (inf2/S2/Int/Hm.PPT/11/4/2017) }
$$

Besides that, during the halaqah the students will be consistently reminded of the Hereafter and are greatly encouraged to increase their acts of worship to Allah SWT to achieve a good and righteous end. While attending the halaqah, the students will also be more motivated to stand firm with the norms within the boundaries of the Islamic faith through their numerous acts of worship. Moreover, by performing all their duties as righteous 
Muslims there is a higher possibility of attaining happiness in this world and also in the next world (Hafiz, 1996).

Islamic education through the implementation of the halaqah method puts a great emphasis on certain aspects such as fardhu ain and fardhu kifayah. By doing this, it will have a positive impact which will lead to the development of good character that only seeks to gain the blessings of Allah SWT in everything that one does. The sense of purpose and also responsibility as good Muslims have been deeply ingrained in the hearts and minds of the students. As a result, the students will have a deeper sense of purpose in life which is to ultimately gain the blessings from the One who truly matters most- Allah SWT. Righteous deeds done to gain the blessings of Allah SWT is the one factor that differentiates man from animals. Islamic education stresses on this important element in the development of good character as the servant and caliph of Allah SWT in this world. In general, the educational aspects greatly encouraged in Islam whether related to fardhu ain or fardhu kifayah are all related to our relationship with Allah SWT, our relationship with others and the surrounding environment which are all deemed as acts of worship to Allah SWT.

\section{Development of Good Character}

Islamic education emphasises spiritual growth which will lead to good character and values. This inadvertently will create a peaceful and harmonious environment in the process. Moreover, Islamic education also puts an emphasis on knowledge that will lead to the growth and development of an individual in terms of spirituality, intellect, physicality, good character, and social values. The main aim of Islamic education is to produce holistic individuals whose main goal is to remain subservient to Allah SWT while having a firm grasp of Islamic teachings based on the Holy Al-Quran and Al-Sunnah.

Due to the fact that the pondok learning institution plays a pivotal role in determining the right mindset and good character of students, the approach used by the teachers in imparting knowledge will have a deep impact on the character and personality development of the students. The halaqah method puts great emphasis on internal elements which include akhlak (good character) and adab (manners) as those are the very essence of halaqah. These elements have the power to create a positive impact in the students to become stronger spiritually and mentally. By gaining this kind of internal strength, the students will be able to withstand any external pressure or conflict in the near future. Besides that, they are also taught the differences between mahmudah and mazmumah. As a result, numerous renowned religious scholars were produced by the pondok learning institutions during its glory days in the past. The emphasis on good character and manners in acquiring knowledge is explained in the following transcription of an interview:

"I believe that the physical apsect of a learning method should be emphasised such as halaqah whereby we should take into consideration the manner in which it will be conducted. This includes sitting cross-legged across the teacher. However if the spiritual aspects or the roh of the halawah such as good manners are neglected, it will have an adverse impact on the development of good character and level of knowledge acquired by the students"

$$
\text { (inf4/L1/Int/Hm.PLT/13/3/2018) }
$$

When there is more emphasis on putting to practice the values learnt, this will enable the students to receive the blessings of the acquired knowledge. During the halaqah, one of the values that should be applied by the students is to pay close attention to the teaching of 
the teacher while humbly bowing their heads when they meet the teacher.Besides that, the students should be serious and strive hard to listen to the teaching and explanation of their teacher particularly those related to the hereafter. Moreover, the students should show their appreciation and respect by not talking or playing around while the teacher is teaching. In addition, the students should refrain from not only offending the teacher but also their peers. This emphasis is shown in the following transcription:

"Similar to halaqah, aspects contained in the halaqah will mainly help students to achieve their objectives and goals in religious education. Other aspects such as the teaching method of the teacher, the attitude of the students, the relationship between teacher and students, and the good character of students are the benchmark of success that proves the effectiveness of the halaqah method in producing high quality students. In conclusion, the positive element that has been applied with the halaqah method is important in ensuring the success of the other elements in the implementation of the halaqah method"

$$
\text { (inf4/L1/Int/Hm.PLT/13/3/2018) }
$$

Certain values as promoted in Islam are also applied in religious gatherings or halaqah which include sitting in an orderly fashion to reflect good manners. Students are also discouraged from putting their books on the floor, not giving their backs to their teachers, holding their books in a respectful manner, remaining silent while the teacher is explaining and also when the azan is heard as well as accepting the answers given by their teacher without any scepticism (Hafiz, 1996). Based on the observation of the chosen pondok learning institutions, it can be deduced that the students truly put into practice the values and manners that were learnt in the halaqah. The emphasis of these aspects are shown in the following transcription of an interview:

"The manners and character of the pondok students were developed at the pondok. It is apparent that the halaqah has made a deep impact on the character development of the students. Moreover, the text entitled Pelita Penuntut or the Beacon of Learners that was used as reference also promoted good manners and character in learning. We, the students, also become closer to our teachers when we sit and learn using the halaqah method"

$$
\text { (inf2/S2/Int/Hm.PPT/11/4/2017) }
$$

"To me...the effect.... because besides the fact that we are taught religious knowledge at the pondok...aspects such as good manners were also further emphasized by the teachers and pondok authorities... The way to interact, the way of life, the manner in acquiring knowledge are some examples.... have to be obeyed by the students.... When we are always in the halaqah, we will become closer to the teacher leading that particular halaqah"

$$
\text { (inf3/S3/Int/Hm.PPT/8/8/2017) }
$$

\section{Spiritual Development}

Based on the Islamic perspective, spirituality is the intrinsic element that is intangible and cannot be explained using the five senses. This spiritual element is closely linked to the relationship we have with Allah SWT that is developed through elements such as the soul, intellect, spirit and heart. These elements have a strong influence in developing the character 
of an individual in terms of level of faith, good behaviour and strong character(Sudi et.al, 2016).

The halaqah method assists the students to develop their sense of spirituality through gaining knowledge of akidah and tasawwuf. The traditional texts of knowledge which are either written in Jawi or Arabic language are the main texts used as reference by the teachers and students of the pondok learning institution. The halaqah method at the pondok has been in use throughout the years since the pondok was first establised. Furthermore, the Quranic halaqah puts great emphasis on learning the Al-Quran properly in accordance of Islamic teachings. The memorisation process of the Al-Quran is also conducted during the halaqah. The teachers will thoroughly evaluate the recitation of the holy verses by their students based on the mashaf or Quranic verses memorised by the respective students.

During the halaqah, the teachers will give an in-depth explanation to their students on the greatness of Allah SWT with the purpose that the latter will truly understand the Almighty Creator. The explanation made by the teachers are usually accompanied by recitation of zikir to Allah SWT as a form of reverence to Him. Besides that, salutations to the Prophet Muhammad (PBUH) are also made to show due respect to the holy prophet (PBUH). Indeed, by doing the above, the students will gain a better understanding and would have internalised the religious knowledge they received. As a result, they will develop a deep respect for their teachers or religious scholars that have taken great pains to impart religious knowledge to them.

In addition, other acts of worship namely the five daily prayers, the non-compulsory prayers such as Dhuha, Qiamullail, Tahajud and also zikir are the examples of religious activities that when performed sincerely and consistently will strengthen the level of faith and spirituality of the teachers and most importantly, the students. Activities based on religious matters are always held at the pondok. These activities are conducted to ensure the teachers and students have a strong level of faith in Allah SWT and the Islamic teachings, are steadfast in performing acts of worship, apply the positive values in daily life, and also perform other activities that help propogate Islam to the community. The pondok community also make social contributions to the surrounding community. People who live in the nearby vicinity of the pondok will usually invite the teachers and students to perform special prayers for the deceased and to recite talqin during the funeral, attend tahlil events, perform hajat prayer, recite Yaasin or the Holy Al-Quran, to give religious talks either at the surau or masjid as well as provide appropriate treatment related to spiritual healing since the teachers and students are well-verse in religious matters.

\section{Developing a Sense of Unity}

The halaqah method is an effective learning method because the teacher and students are sitted to face one another. The students are sitted cross-legged and are sitted nearby to their peers. From a psychological standpoint, this will strengthen the bonds of kinship of everyone involved while creating a loving and harmonious environment. Through the halaqah method, every student will feel free to contribute their ideas without hesitation. Psychologically speaking, the halaqah method also creates a nurturing and conducive learning environment whereby everyone feels at par with each other and thus eliminating any sense of superiority over one another. Indeed, this will help strengthen the sense of brotherhood since the students will feel at ease with one another. There will be no social or status barriers which will encourage students to freely express their views. In the halaqah, all students are 
treated fairly without taking into account social status, economic background, level of Islamic knowledge and so forth (Rosmanah, 2013). This is evident in the following transcription:

"In addition, when we are studying in the same halaqah the relationship among our peers is further strengthened. The ones who are more knowledgeable continue to encourage others to learn as much as they could"

(inf1/S1/Int/Hm.PLT/22/3/2017)

"Halaqah can also strengthen the sense of brotherhood and develop a sense of tolerance. The students can also learn and live together either at the hostel or pondok"

$$
\text { (inf2/S2/Int/Hm.PPT/11/4/2017) }
$$

"Learning through the halaqah method will strengthen the relationship among friends and teachers because we often sit together"

(inf3/S3/Int/Hm.PPT/8/8/2017)

In addition, learning in a group has a tremendously positive impact on the students. The fact that the students have to learn together will make them more motivated to learn due to the moral support they get from each other in the halaqah (Baharudin et.al., 2013). Being highly motivated is the catalyst that will lead to an active exchange of ideas while making students strive harder in gaining knowledge. Moreover, the halaqah method also strengthens the bonds of brotherhood among the students. The halaqah method also promotes interaction and discussion between the teacher and students even after lessons are over. Generally, the discussion is a result of what the students understand from the previous lesson (Sahputri, 2016).

During the halaqah, naturally the teacher will gain a deeper understanding of his students due to the interaction and constant exchange of ideas among them. The former will gain a better insight of the characteristic of the latter and their potential. This is mainly because the teacher and students are mostly positioned close to each other which encourages active interaction and discussion. The way they are sitted to each other will inadvertently strengthen the ties of kinship and promote solidarity either between the teacher and students or among the students themselves. This is evident from the transcription below:

"...The teacher and Head of Mutala'ah will get to know the students" (inf2/S2/Int/Hm.PPT/11/4/2017)

"By learning using the halaqah method, it will strengthen the ties of kinship between the students and teachers because we are sitted close to each other"

$$
\text { (inf3/S3/Int/Hm.PPT/8/8/2017) }
$$

According to Zarnuji (2017), students show their respect for their teacher by following instructions and avoiding from offending their teacher. A warm relationship between students and teacher will be fostered in a loving and harmonious environment. However if a teacher does not have a sense of love and tolerance towards his students, the knowledge gained is futile as it has lost the essence of blessedness from the teacher. Thus the knowledge gained will not bring any benefit to the students. According to Abdullah (2018), there needs 
to be a harmonious environment whereby the teacher and students need to respond positively to each other as the former is the mentor who will guide the latter. This is further explained in the transcription of an interview below:

"...In other words, the relationship between the teacher and students will be fostered especially in a harmonious environment because the former is the mentor to the latter. These elements is the essence of halaqah. This is most important"

$$
\text { (inf4/L1/Int/Hm.PLT/13/3/2018) }
$$

In addition, the respect shown to teachers is ingrained in the Malay culture particularly the students at the pondok because it is a way of acknowledging and giving due recognition to the knowledge, skill and leadership possessed by the teachers. Teachers are given such a prestigious position by the pondok community and as a result the surrounding local community also holds them with a high regard as well.

In terms of community welfare, the pondok community has actively participated in various activities that are a reflection of Malay cultural values that emphasise on a sense of community and togetherness. For instance: organising social gatherings, tahlil, Yaasin recitations, funerals, Islamic healing treatment, and religious related activities. In the process, this elevates the status of religious scholars and protects the sanctity of Islam.

\section{Character Development}

Halaqah is a system and an alternative method of dakwah or propagating religion in Islamic education that effectively leads to the development of a dynamic Islamic character. This is because through the halaqah method, many Muslims show a deep interest in learning about Islamic knowledge. Halaqah is a method that promotes religious values that include a deep understanding and application of Islamic teachings. As a result, the community is impressed with the values shown in the actions of the Muslims. The halaqah method is systematic and has consistently produced many learned individuals that truly grasped the Islamic teachings. Not only are they well-versed in Islamic teachings, they are also adept at self-control and have a positive mindset despite facing certain adversities in life (Rosmanah, 2013). The halaqah method has successfully produced numerous religious scholars of high calibre who have earned the respect of the community. This is evident in the way these scholars such as those with the status of lebai have made immense contributions in terms of propagating Islam and also Islamic education either at the masjid or surau (Teh, 1993). The transcription of the interview is shown below:

"...besides being taught religious knowledge at the pondok...aspects such as good behaviour and character were also emphasised by the teachers...The way of interacting with others, the manner in which to conduct ourselves while learning for instance...."

$$
\text { (inf3/S3/Int/Hm.PPT/8/8/2017) }
$$

\section{Produce Religious Scholars}

The pondok learning institutions put a great emphasis on matters related to knowledge, acts of devotion, akhlak and discipline. This process is capable of producing religious scholars in Islamic education who are able to provide the appropriate resolution to any arising problem in the community (Rahman et.al., 2014). The halaqah method is one such method that can be used with anyone regardless of their education background. The main purpose of halaqah is 
to provide an avenue for individuals to gain an in-depth knowledge of Islam sincerely and with full commitment. Moreover, the halaqah method has produced many renowned scholars of Islam not only in the Middle East but also South-East Asia. This is evident in the following transcription of an interview below:

"...The aim of the halaqah method is to produce religious scholars, this is evident in the past during the glory days of the pondok institution. We need to emphasise elements of spirituality and ta'dib in the learning methods such as halaqah becaused these elements are the essence of halaqah"

$$
\text { (inf4/L1/Int/Hm.PLT/13/3/2018) }
$$

Religious scholars have done their part in making an immense contribution to Islamic education in terms of imparting their knowledge to the Muslim community with the utmost sincerity. These halaqah of knowledge are normally attended by all walks of life. As a result, the pondok learning institution that was established by the religious scholars had reached its peak in Malaysia in the 19th century. Although the response has waned somewhat, the legacy of the pondok learning institutions still remain as the centre of excellence in Islamic religious knowledge that successfully produced numerous religious scholars until the present day.

\section{Conclusion}

The education system at the pondok learning institutaion still implements the same traditional methods and the halaqah method still has a deep impact on the level of mastery and expertise of students. Eventhough the methods being implemented are not modern, the methods are still considered relevant due to their effectiveness in imparting knowledge and values to the students until the present day.

The achievement of malakah as mentioned by Ibnu Khaldun (1332-1406 M) can be seen in the culture at these pondok learning institutions. Indeed, the halaqah method has a positive impact on the learning culture particularly, the students. As a result, the pondok learning institutions have immensely contributed to the development of Islamic education in the Archipelago. The religious scholars and students have become role models for the community at large as they are a reflection of the knowledge they had acquired. In addition, the scholars and students are also active in organising numerous religious events for the people as a part of community service.

The positive effects of the halaqah method are numerous and some of them include producing holistic individuals, internalising the knowledge and values acquired, becoming role models for the community and also being on par with other learned individuals from other learning institutions. Although the education system at the pondok is considered traditional to the modern society, the role of the pondok learning institution can no longer be denied as it has a positive impact while still remaining true to its Islamic identity.

This study has shown the significant influence of pondok learning institutions and its education system upon the development and mastery of knowledge. From a theoretical perspective, the malakah concept is the benchmark in which the achievement, mastery, practical application, talent and level of knowledge of an individual is measured. In terms of providing a sound education to the students of the pondok learning institutions, the halaqah method has truly made a positive impact as it has managed to achieve the primary goal of imparting knowledge which is to produce holistic individuals who are not only highly knowledgeable but also possess remarkable character. Although the malakah concept can be implemented at all levels, the fact that it is implemented particularly at pondok learning 
institutions and have successfully produced numerous learned and renowned religious scholars is testament that indeed the malakah concept is remarkable. The achievement of the malakah concept is due to the good character and competence of the students at the pondok learning institutions as can be proven through their display of excellent character, knowledge they have acquired and success they have accomplished. Hence, the malakah concept can be further expanded and implemented at other learning institutions particularly the halaqah method as it has been proven to have a resounding positive impact. This particular study has inadvertently shown that the pondok learning institutions still remain relevant today in the globalised world we live in. This is evident as the pondok learning institutions have produced countless Muslim individuals who not only possess good character, display impressive personality, but are also highly knowledgeable in religious matters and also worldly matters. Therefore, the malakah concept and halaqah method embody the true essence of Islamic education.

\section{References}

Anwar, S. (2008). Konsep Pendidikan Ibnu Khaldun. Jurnal Ta'lim Vol. 6, 11-17.

Badaruddin, F. (2007). Pendidikan Pondok Dan Peranannya di Tanah Melayu Abad Ke 19 M. In Zin, F.M. (Ed.). Islam Di Tanah Melayu Abad Ke 19 M. Shah Alam: Karisma Publications Sdn. Bhd., 16-25

Baharudin, D. F., Jailani, M. R. M., \& Sumari, M. (2013). Islamic Study Circle (Halaqah) As A Teaching Method In Counselor Education: Students' Experience. Proceeding of the World Conference on Integration of Knowledge (WCIK 2013),25-26 November 2013, Langkawi, Malaysia, 129-134

Dhofier, Z. (2011). Tradisi Pesantren. Jakarta : Penerbit LP3ES

Hafiz, A. U. (1996). Maqasid Halaqat al-Ta'lim wa Wasailiha. Retrieved from http://www.habibomar.com

Hambali, K. M. K., \& Kadir, N. A. A. (2005). Pengaruh al-Azhar Terhadap Sistem Pendidikan Islam di Tanah Melayu-Malaysia. Jurnal Usuluddin Bil.22, 27-56

Hamid, A. F. A. (2010). Islamic Education in Malaysia. Singapore: S.Rajaratnam School of International Studies

Hamzah, S. R. (2010). Konsep Pendidikan Islam Menurut Pemikiran Ibn Khaldun. Kuala Lumpur: Scholar Mind Publishing

Ishak, A. (1995). Pendidikan Islam dan Pengaruhnya di Malaysia. Kuala Lumpur : Dewan Bahasa dan Pustaka

Ismail, S., Ismail, B., \& Noh, M. A. C. (2014). Kebijakan Islam Dalam Transformasi Sistem Pendidikan Di Malaysia: Suatu Tinjauan ke Atas Sistem Pendidikan Islam. Proceeding of the Wacana Pendidikan Islam Siri ke-10,15 - 17 December 2014, Fakulti Pendidikan UKM \& Majlis Agama Islam Sabah (MUIS), Kota Kinabalu Sabah, Malaysia, 1-11

Ismail, S., Ismail, Z., \& Hamjah, S. H. (2014). Kemapanan Institusi Pondok Di Kelantan: Kajian Konsep. Jurnal Islamiyyat 36(1), 49-52

Majid, M.K.A. \& Hamat, M.F. (2005). Pemikiran Ibnu Khaldun Mengenai Sifat dan Amalan Negatif yang Boleh Meruntuhkan Kepimpinan Islam. Jurnal al-Tamaddun Bil.1 Disember 2005, 137-166

Manaf, A. A. (2001). Sejarah Sosial Masyarakat Malaysia. Kuala Lumpur: Utusan Publications \& Distributors Sdn. Bhd.

Mohammad, A. (2008). Sumbangan Tamadun Islam Dalam Kehidupan Masyarakat Di Alam Melayu Hingga Abad Ke-17 M. Jurnal al-Tamaddun Bil.3 (1), 68-84. 
Muslimin, A. (2015). Implementasi Metode Halaqah Dan Resitasi Dalam Tahfiz Al-Quran Di SDIT EL-HAQ, Banjarsari Buduran Sidoarjo. Jurnal Adabiyah:Pendidikan Islam Volume 1, No. 1. Retrieved from ojs.umsida.ac.id/index.php/ajpi/article/download/164/172, $55-61,55-62$

Na'miy, A. A. A. (1994). Kaedah dan Teknik Pengajaran Menurut Ibnu Khaldun dan al-Qabisi. Kuala Lumpur: Dewan Bahasa dan Pustaka

Noh, A.. M. (2015). Falsafah Pendidikan Islam: Beberapa Kaedah Pengajaran dan Pembelajaran Menurut Ibn Khaldun. Proceeding of the Konferensi Antarabangsa Islam Borneo VIII (KAIB VIII 2015),2-3 September 2015, Universiti Islam Sultan Shariff Ali, Brunei Darussalam, 341-343

Qadiri, A. (1993). Adab Halaqah. Bandung: PT. al-Maarif

Rahim, A. F. A., \& Bakar, M. Z. A. (2015). Glokasi dan Cabaran Sekolah Pondok di Malaysia. In Lah, S.C. \& Esa, N. (Eds.). Ilmu, Tradisi dan Kelestarian dalam Kearifan Tempatan. Pulau Pinang : Penerbit Universiti Sains Malaysia, 20-30.

Rahman, N. A. A., Rahim, R. A. A., Noor, R. M., \& Ismail, P. (2014). Formula Ketatanegaraan di Terengganu Dalam Kitab Itqan al-Muluk bi Ta'dil as-Suluk. In Salbani, A.M., Othman, S. \& Hamid, R.A. (Eds.). Amalan Kearifan Tempatan Dalam Masyarakat Melayu/Nusantara Pulau Pinang : Universiti Sains Malaysia

Rawi, M. M., Baharuddin, H., Lubis, M. A., \& Romli, S. A. (2015). Institusi Pondok Dalam Sistem Pendidikan Islam di Malaysia. Proceeding of The 7th International Workshop And Conference Of Asean Studies On Islamic And Arabic Education And Civilization, 3 June 2015, Fakulti Pendidikan Universiti Kebangsaan Malaysia, 3-15

Rosmanah, M. (2013). Pendekatan Halaqah Dalam Konseling Islam Dengan Coping Stress Sebagai Ilustrasi. Jurnal Intizar, Vol. 19, No.2, Retrieved from download.portalgaruda.org/article.php, 301-322

Saadon, R., Arifin, K., \& Saat, I. (2016). Perkembangan Pendidikan Orang Melayu di Malaya Sebelum Kemunculan Western-Type-Education. Jurnal Perspektif, Jil.8 Bil.2, 79-96

Sahputri, R. (2016). Implementasi Model Pembelajaran Halaqah Pada Mata Pelajaran PAI Di SMA Negeri 11 Surabaya. Bachelor Art Thesis, Fakultas Tarbiyah dan Keguruan Universitas Islam Negeri Sunan Ampel Surabaya

Sudi, S., Sham, F. M., \& Yama, P. (2016). Spiritual Dalam al-Quran. Proceeding of the International Conference On Akidah, Dakwah and Syariah 2016 (IRSYAD 2016). Retrieved from http://conference.kuis.edu.my/irsyad/eproceeding/2016/1028irsyad-2016.pdf, 351-370

Suhid, A., \& Fakhruddin, F. M. (2012). Gagasan Pemikiran Falsafah Dalam Pendidikan Islam: Hala Tuju dan Cabaran. Journal of Islamic and Arabic Education 4(2), 57-70.

Sulaiman, M. (2013). Islam dan Transformasi Sosial Masyarakat Melayu Malaysia: Suatu Kajian Eksploratori. Proceeding of the International Conference on Social Science Research (ICSSR 2013),4-5 June 2013, Penang, Malaysia, 778-800

Teh, W. Z. W. (1993). Pengemaskinian Sistem Pengajian Pondok di Pulau Pinang. In Rahman, I.A. (Ed.). Pendidikan Islam di Malaysia. Bangi : Penerbit Universiti Kebangsaan Malaysia, 105-118

Umami, F. R. (2015). Pembentukan Karekter Religius Siswa Melalui Metode Halaqah di SDIT Harapan Bunda Purwokerto. Master Thesis, Fakultas Tarbiyah dan Ilmu Keguruan Institut Agama Islam Negeri (IAIN) Purwokerto

Yahya, M. (2001). Tamadun Islam. Kuala Lumpur: Penerbit Fajar Bakti Sdn. Bhd. 
Zainol, M. Z., Hashim, A., \& Rahim, M. M. A. (2018). Persepsi Guru Pendidikan Islam Terhadap Ilmu Menurut Konsep Malakah Ilmiyyah Ibnu Khaldun. Jurnal Sains Humanika Bil. 10, Isu 3-4. Retrieved from www.sainshumanika.utm.my. 115-120

Zarnuji, B. A. (2017). Ta'lim al-Muta'alim/Pelita Penuntut. Selangor : al-Hidayah Publications Zeki, M. Z. M., \& Moshidi, N. (2017). Keberkesanan Teori Malakah Dan Tadrij Dalam Amalan Pengajaran Guru Pendidikan Islam Di Sekolah Pedalaman. Proceeding of the Seminar Kebangsaan Isu-Isu Pendidikan (ISPEN 2017), 12 October 2017, Kolej Universiti Islam Antarabangsa Selangor, Malaysia, 25-34

\section{Interviews}

Abdullah, L. (interview on $13^{\text {th }}$ March 2018), Leader of Pondok Lubuk Tapah, Pasir Mas, Kelantan

Radzi, M. F. F. (interview on $8^{\text {th }}$ August 2017), student in Pondok Pasir Tumbuh, Kota Bharu, Kelantan

Fazli, M. I. A. (interview on $22^{\text {nd }}$ March 2017 ), student in Pondok Lubuk Tapah, Pasir Mas, Kelantan

Saidin, M. A. A. (interview on $11^{\text {th }}$ April 2017), student in Pondok Pasir Tumbuh, Kota Bharu, Kelantan 